\title{
Sequence comparison of the central region of the glycoprotein gene of neutralizable, non-neutralizable, and serially passed isolates of viral haemorrhagic septicaemia virus
}

\author{
P. E. V. Jørgensen ${ }^{1, *}$, K. Einer-Jensen ${ }^{1}$, K. H. Higman ${ }^{2}$, J. R. Winton ${ }^{2, * *}$ \\ 'Danish Veterinary Laboratory, Hangovej 2, DK-8200 Århus N, Denmark \\ ${ }^{2}$ Northwest Biological Science Center, 6505 NE 65th Street, Seattle, Washington 98115 , USA
}

\begin{abstract}
The region of the viral haemorrhagic septicaemia virus glycoprotein gene coding for amino acids 142 to 357 was sequenced and compared among 6 isolates of the virus from Jainbow trout in Denmark. Isolates were selected that were strongly neutralized by polyclonal and monoclonal antisera, not neutralized by antisera, or that represented more than 500 serial passages in cell cultures. The overall diversity within this region of the glycoproten was $5.4 \%$ at the nucleotide level and $6.9 \%$ at the amino acid level. Most of the variation was in the portion of the proten from amino acids 210 to 290 where substitutions were found in 13 of the 80 amino acids $(16 \%)$. In contrast, the central portion of the glycoproteln of the F1 reference strain of the virus was remarkably stable during 510 passes in cell culture, accumulating only a single amino acid substitution. Differences between the neutralizable and non-neutralizable isolates were found in the regions from amino acids 257 to 259 and from 283 to 288
\end{abstract}

KEY WORDS: Rhabdovirus Glycoprotein Antigenic site VHSV sequence variation

Viral haemorrhagic septicaemia (VHS) is a severe systemic infection of fish that principally affects cultured rainbow trout Oncorhynchus mykiss in Europe (Wolf 1988, Jørgensen 1992). The disease is caused by a rhabdovirus termed Egtved virus or VHSV (Jensen 1965, Wolf 1988). Because sequence data exist for only a limited number of strains of VHSV, little is known about the extent of genetic diversity among various isolates of the virus. In recent years, isolates of the virus that were not neutralized by polyclonal or monoclonal antibodies made against the $F 1$ reference strain of VHSV have been encountered with increasing fre-

\footnotetext{
- Deceased January 1, 1995

"Addressee for correspondence; E-mail: jim_winton@nbs.gov
}

quency in connection with outbreaks of VHS in Danish trout farms (Olesen et al. 1993). Because most neutralizing epitopes of rhabdoviruses (e.g. rabies virus, vesicular stomatitis virus, infectious haematopoietic necrosis virus) are located within the central portion of the viral glycoprotein (Luo et al. 1988, Benmansour et al. 1991, Huang 1993), we determined the number and location of nucleotide and deduced amino acid substitutions in the analogous region of the gene encoding the glycoprotein (G) of VHSV and compared neutralizable and non-neutralizable isolates with respect to such differences. Also, we determined the nucleotide and amino acid substitutions accumulating in the glycoprotein gene of the F1 reference strain of VHSV during more than 500 passages in fish cell lines to obtain information about the genetic stability of the virus during serial passage in tissue culture. To facilitate our work, we used the reverse transcriptase, polymerase chain reaction (RT-PCR) to amplify a 1000 nucleotide region of the $\mathrm{G}$ gene of VHSV. The resulting RT-PCR product was used as a template for fluorescent terminator, cycle sequencing of both DNA strands of a 650 nucleotide region coding for amino acids 142 to 357 of the viral glycoprotein.

Materials and methods. Six isolates of VHSV were used in this study. Voldbjerg (DK-3592B), Hjarnø (DK6137), Vejen (DK-5727), Nørre $\AA$ (DK-6045), and Nielsby (DK-5727) were obtained at low passage levels and the $F 1$ reference strain was obtained at passage levels 13, 256, and 510 from the Danish Veterinary Laboratory, Århus, Denmark. All isolates were from rainbow trout suffering acute VHS in Danish trout farms. The Voldbjerg isolate and the 3 passage levels of the F1 strain were strongly neutralized by a panel of monoclonal and polyclonal antibodies made against the $F 1$ reference strain of VHSV while the other iso- 
lates were not neutralized (or neutralized at very low efficiency) by these reagents (Olesen et al. 1993). The F1 strain was isolated in 1962 using primary trout ovary cells and has been passed more than 500 times in cell culture. The vast majority of the passages were performed under conditions of low multiplicity of infection (MOI) using RTG-2 cells. Cloning by plaque selection was performed 3 times in FHM cells around passage level 100 while a few passages were made using EPC cells. The remaining isolates were obtained using BF-2 cells and had been passed 4 to 6 times at moderate $\mathrm{MOI}$ in cultures of BF-2 and EPC cells

For production of virus and viral genomic RNA, CHSE-214 cells were grown in plastic flasks or multiwell dishes at $20^{\circ} \mathrm{C}$ using Eagle's minimal essential medium supplemented with $10 \%$ fetal bovine serum and standard concentrations of penicillin and streptomycin. When cells were grown in open culture systems, the medium was buffered with Tris (pH 7.6), whereas in closed systems, a sodium bicarbonate buffer ( $\mathrm{pH} 7.4$ to 7.6 ) was used. Following inoculation with stock virus, cultures were incubated at $15^{\circ} \mathrm{C}$ for 3 to $5 \mathrm{~d}$. At the time of harvest, the cultures showed complete cytopathic effect.

Total RNA was selectively extracted from a $0.5 \mathrm{ml}$ aliquot of membrane-filtered $(0.45 \mu \mathrm{m}$ pore size) culture fluid by addition of $0.7 \mathrm{ml}$ of a solution containing phenol, 2-mercaptoethanol, and guanidinium thiocyanate (RNAzol B, Cinna/Biotecx). After vigorous shaking for $10 \mathrm{~min}$ at room temperature, $70 \mu \mathrm{l}$ of a $24: 1$ mixture of chloroform and isoamyl alcohol at $-20^{\circ} \mathrm{C}$ was added and the tube vortexed for about $1 \mathrm{~min}$. Subsequently, the tube was centrifuged at $15800 \times g$ for $15 \mathrm{~min}$ in a microfuge. The upper aqueous phase was carefully transferred to a clean microfuge tube and mixed with an equal volume of isopropanol at $-20^{\circ} \mathrm{C}$. The mixture was vortexed briefly and left on crushed ice for $15 \mathrm{~min}$. Then, the tube was centrifuged at 15800 $\times g$ for $15 \mathrm{~min}$ and the supernatant carefully removed and discarded. The RNA pellet was washed with $70 \%$ ethanol and the centrifugation repeated. Most of the ethanol was removed, and the RNA dried in a vacuum centrifuge. The RNA was dissolved in $100 \mu \mathrm{l}$ of water and stored at $-80^{\circ} \mathrm{C}$ until used.

The reverse transcriptase, polymerase chain reaction (RT-PCR) was performed using a thermal cycler (Perkin-Elmer Model 9600). Briefly, reaction volumes of $50 \mu$ l were made containing $21 \mu$ l of water, $5 \mu l$ of $10 \times$ PCR buffer, $16 \mu$ I deoxynucleotidetriphosphates at $1.25 \mathrm{mM} \mathrm{\mu l}^{-1}, 2.5 \mu \mathrm{l}$ of the sense primer at $20 \mathrm{pM} \mathrm{\mu l}^{-1}$. $2.5 \mu \mathrm{l}$ of antisense primer at $20 \mathrm{pM} \mu \mathrm{l}^{-1}, 0.5 \mu \mathrm{l}$ of avian myeloblastosis virus reverse transcriptase (United States Biochemical) at 2.5 units $\mu l^{-1}, 0.5 \mu l$ of $\mathrm{Taq}$ polymerase (Perkin-Elmer-Cetus) at 5 units $\mu \mathrm{l}^{-1}$, and $10 \mu \mathrm{l}$ of crude RNA, prepared as described. The nucleotide sequences of the sense and antisense primers were 5'-CAGCTTCTTTGGAGGGC-3' and 5'TTAGTGGAAAGATCGGATG-3', respectively. These were selected from the published sequence of the Voldbjerg strain of VHSV (Lorenzen et al. 1993) to yield an RT-PCR product of about 1000 nucleotides in length. The thermocycler was programmed for RTPCR as follows: reverse transcription for $15 \mathrm{~min}$ at $50^{\circ} \mathrm{C}$, sample denaturation and $\mathrm{RT}$ inactivation for 2 min at $95^{\circ} \mathrm{C}$ followed by 30 cycles of 2-step PCR (denaturation for $30 \mathrm{~s}$ at $95^{\circ} \mathrm{C}$ and primer annealing/ synthesis/extension for $60 \mathrm{~s}$ at $60^{\circ} \mathrm{C}$ ) with final extension for 7 min at $60^{\circ} \mathrm{C}$. Minimum ramp times were used between temperature changes.

Aliquots of the RT-PCR products were gel-purified in $2 \%$ low melting point agarose (NuSieve) in $1 \times$ TAE buffer. Following electrophoresis at $40 \mathrm{~V}$ for about $40 \mathrm{~min}$, the gel was stained for $10 \mathrm{~min}$ with ethidium bromide, bands in the gel were briefly visualized in UV light, and the DNA was rapidly cut out of the gel for further purification. The excised PCR products were transferred to a microfuge tube, heated to $70^{\circ} \mathrm{C}$ for 2 min to melt the agarose, and concentrated using a spin column (Wizard Magic Prep, Promega) according to the manufacturer's instructions. The purified DNA was resuspended in $50 \mu \mathrm{l}$ of water, quantified by spectrophotometer, and stored at $-80^{\circ} \mathrm{C}$ until used for sequencing.

Both strands of the central portion of the RT-PCR product were sequenced using 4 primers and a dyeterminator cycle sequencing kit (PRISM, Applied Biosystems, Inc.) according to the instructions of the supplier. The region of the PCR product selected for sequencing corresponded to the 650 nucleotides coding for amino acids 142 through 357 of the VHSV glycoprotein. The sense primers were 5' -ATCACGAGTACCCGTTCTTCC-3' and 5'-ATCACAGGGTGGTCAAGG-3' while the antisense primers were $5^{\prime}$ ACCTCGCATGATTTGACCG-3' and 5'-TGCATGCCATTGTGAGTCC-3'. The sequence data were stored, aligned, and analyzed using the PC Gene (Intelligenetics) software programs.

Results. Agarose gel electrophoresis revealed that the RT-PCR reactions using genomic RNA from each of the VHSV isolates gave rise to a single band (Fig. 1). When run with molecular weight markers, the RT-PCR products had relative mobilities corresponding to dsDNA of the expected size of approximately 1000 base pairs. Fluorescent terminator cycle sequencing of both strands of the RT-PCR products produced unambiguous sequence data and the product from the Voldbjerg isolate gave results which were in perfect agreement at the nucleotide level with results from conventional sequencing of the $\mathrm{G}$ gene of this isolate (Lorenzen et al. 1993). 


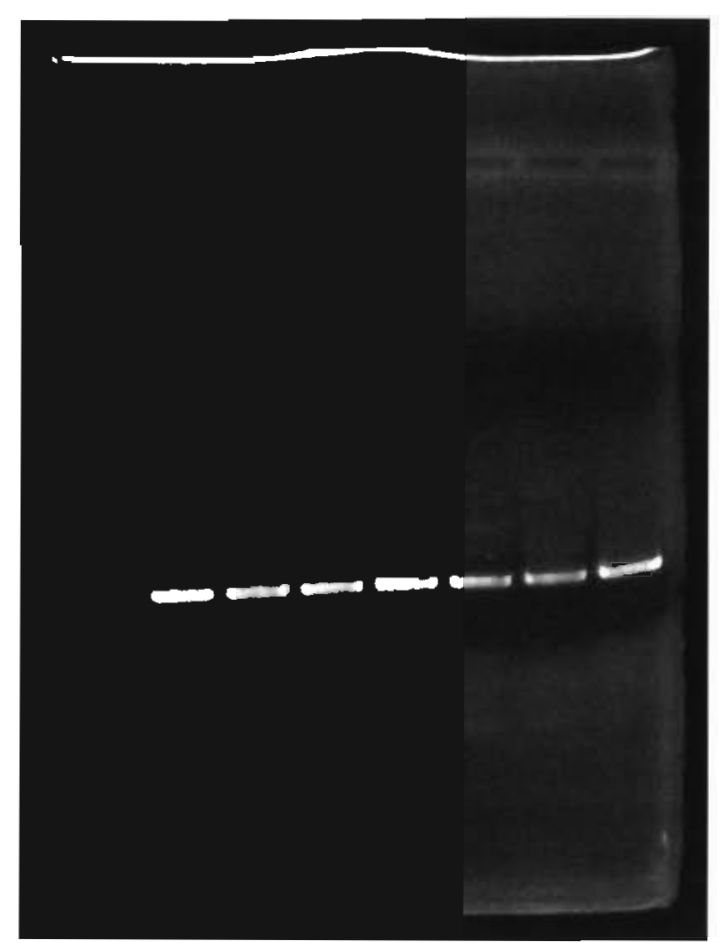

Fig. 1 Agarose gel electrophoresis of the products resulting from reverse transcriptase, polymerase chain reaction (RTPCR amplification of the central portion of the glycoprotein gene of different isolates of viral haemorrhagic septicaema virus. The bands contain double-stranded RT-PCR products of approximately 1000 base pairs that were excised, purified, concentrated, and used as templates for automated fluorescent sequencing

Comparisons of the 650 nucleotides and 216 deduced amino acids of the 8 RT-PCR products revealed from 0 to 30 nucleotide differences ( 0 to $4.6 \%$ ) and from 0 to 12 amino acid differences ( 0 to $5.6 \%$ ) between the various pairs of sequences (Table 1 ). Overall, amino acid substitutions occurred at 15 of the $216(6.9 \%$ ) residues (Fig. 2). Most of these substitutions occurred in the region between amino acids 257 to 290 and all but one were conservative. No nucleotide differences were detected between passages 13 and 256 of strain $\mathrm{F} 1$ resulting in identical deduced amino acid sequences for this portion of the protein. Between passages 256 and 510, 2 nucleotide substitutions had accumulated, one of which was silent and the other of which resulted in the substitution of lysine for a glutamic acid residue at a codon within the RT-PCR product corresponding to amino acid 259 of the open reading frame of the VHSV glycoprotein (Fig. 2).

The 4 non-neutralizable VHSV strains (Hjarno, Vejen, Nørre $\AA$, and Nielsby) all differed from the neutralizable isolates ( 3 passage levels of $F 1$ and Voldbjerg) by having substitutions in the region of amino acids 257 to 259 (glutamic acid for glycine at position
257 and aspartic acid for glutamic acid at position 259) and in the region of amino acids 283 to 288 (asparagine or arginine for one of the lysine residues at positions 283 to 284 and threonine for alanine at position 288 . One or both of these regions may represent an antigenic site containing a neutralizing epitope.

Discussion. The overall diversity within the central region of the glycoprotein of the 6 isolates of VHSV was $5.4 \%$ at the nucleotide level and $6.9 \%$ at the amino acid level. This is comparable to the variation reported among isolates of a related fish rhabdovirus, infectious hematopoietic necrosis virus (IHNV) as determined by Oshima et al. (1995), who used T-1 ribonuclease fingerprinting to determine that 26 isolates of IHNV differed by slightly less than $5 \%$ at the level of the genomic RNA, and by Nichol et al. (1995), who sequenced the entire glycoprotein and non-virion genes of 12 IHNV isolates and found an overall difference among the glycoproteins of approximately $6.5 \%$ at the amino acid level.

While the non-neutralizable isolates of VHSV might be considered a second 'serotype' of VHSV, the amino acid differences between the neutralizable and the non-neutralizable isolates were much less than the differences found within a single serotype of either the mammalian vesiculovirus, vesicular stomatitis virus (Nichol et al. 1989), or the mammalian lyssavirus, rabies virus (Bourhy et al. 1993). Differences in the glycoproteins between serotypes of the mammalian

Table 1 Matrix of the pairwise similarity scores among the 8 nucleotide and deduced amino acid sequences of the central portion of the glycoprotein gene of 6 isolates of viral haemorrhagic septicaemia virus. Comparisons among 650 nucleotides of the glycoprotein gene and among the 216 deduced amino acids are shown

\begin{tabular}{|c|c|c|c|c|c|c|c|c|}
\hline & 1 & 2 & 3 & 4 & 5 & 6 & 7 & 8 \\
\hline \multicolumn{9}{|l|}{ Nucleotides } \\
\hline 1. F1-13 & - & & & & & & & \\
\hline 2. F1-256 & 650 & - & & & & & & \\
\hline 3. F1-510 & 648 & 648 & - & & & & & \\
\hline 4. Hjarno & 626 & 626 & 623 & - & & & & \\
\hline 5. Norre $\AA$ & 623 & 623 & 620 & 644 & - & & & \\
\hline 6. Voldbjerg & 630 & 630 & 628 & 640 & 637 & - & & \\
\hline 7. Nielsby & 629 & 629 & 627 & 636 & 633 & 639 & - & \\
\hline 8. Vejen & 628 & 628 & 626 & 635 & 632 & 638 & 649 & - \\
\hline \multicolumn{9}{|l|}{ Amino acids } \\
\hline 1. $F 1-13$ & - & & & & & & & \\
\hline 2. F1-256 & 216 & - & & & & & & \\
\hline 3. F1-510 & 215 & 215 & - & & & & & \\
\hline 4. Hjarnø & 205 & 205 & 205 & - & & & & \\
\hline 5. Narre $\AA$ & 204 & 204 & 204 & 214 & - & & & \\
\hline 6. Voldbjerg & 208 & 208 & 207 & 213 & 211 & - & & \\
\hline 7. Nielsby & 206 & 206 & 205 & 211 & 209 & 212 & - & \\
\hline 8. Vejen & 205 & 205 & 204 & 210 & 208 & 211 & 215 & - \\
\hline
\end{tabular}




\begin{tabular}{|c|c|c|c|}
\hline$F 1-13$ & \multicolumn{2}{|c|}{ HEYPFFPEPSCIWMKNNVHKDITHYYKTPKTVSUDLYRRKFLNPDFIEGV } & 191 \\
\hline$F 1-256$ & \multicolumn{2}{|c|}{ HEYPEFPEPSCTWMKAWWHKDITHYYKTPKTVSWDLYRRKPLNPDFIEGY } & 291 \\
\hline$F 1-510$ & \multicolumn{2}{|c|}{ HEYPFEPEPSCIWMKNNVHKDITHYYKTPKTVSVDLYRRKELNPDFIEGV } & 191 \\
\hline Volabjerg & \multicolumn{2}{|c|}{ HEYPFFPEPSCTWMKNNVHKDITHYYKTPKTVSVDLYSRKFLNPDFTEGV } & 191 \\
\hline Hjarno & \multicolumn{2}{|c|}{ HEYPFEPEPSCIWMKNNVHKDITHYYKTPKTVSVDLYSRKELNPDFIEGV } & 191 \\
\hline Norre A & \multicolumn{2}{|c|}{ HEYPEFPEPSCTWMKNNVHKDITHYYKTPKTVSVDLYSRKELNPDETEGV } & 191 \\
\hline Nielsby & \multicolumn{2}{|c|}{ HEYPFFPEPSCTWMKNNVHKDITHYYKTPKTVSVDLYSRKFLNPDEIEGY } & 191 \\
\hline Vejen & \multicolumn{2}{|c|}{ 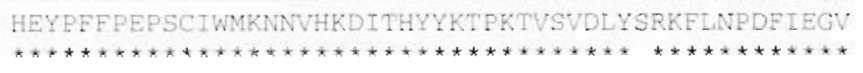 } & 191 \\
\hline F1-13 & \multicolumn{2}{|c|}{ CTTSPCQTHWQGVYWVGATPTAHCPESETLEGHLFTRTHDHRVVKATVAG } & 241 \\
\hline F1-256 & \multicolumn{2}{|c|}{ CTTSPCQTHWQGVYWVGATP TAHCEESETLEGHLETRTHDHRVNKAIVAG } & 241 \\
\hline F1-510 & \multicolumn{2}{|c|}{ CTTSPCQTHWQGVYWVGATPTAHCPESETLEGHLFTRTHDHRVVKAIVAG } & 241 \\
\hline volabjerg & \multicolumn{2}{|c|}{ CTTSPCQTHWQGVYWVGATPKAHCDTSETLEGHLETRTHDHEVVKATVAG } & 241 \\
\hline Hjarno & \multicolumn{2}{|c|}{ CTTSPCQTHWQGVYWVGATPKAHCPT SETLEGHLFTRTHDHRVVKATVAG } & 241 \\
\hline Norre A & \multicolumn{2}{|c|}{ CTTSPCQTHWQGVYWVGAT NAHCETSETLEGHLFTRTHDHEVVKAIVAG } & 241 \\
\hline Nielsby & \multicolumn{2}{|c|}{ CTTSPCQTHWQGVYWVGATP RAHCPTSETLEGHLFTRTHDHRVVKAIVAG } & 241 \\
\hline Vejen & & 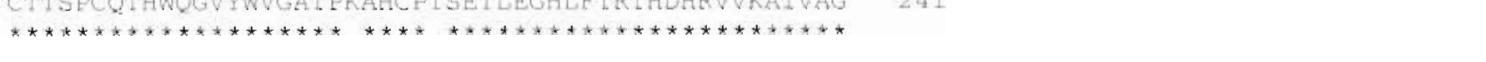 \\
\hline F1-13 & \multicolumn{2}{|c|}{ HHPWGLTMACTVTECGTEWIKTDLGDLIKVTGPGGARKLTPKKCVNADIQ } & 291 \\
\hline$F 1-256$ & \multicolumn{2}{|c|}{ HHPWGLTMACTVTECGTEWIKTDLGDL I KVTGPGGARKLTPKKCVNADIQ } & 291 \\
\hline F1-510 & \multicolumn{2}{|c|}{ HHPWGLTMACTVTECGTKWIKTDLGDLIKVTGPGGARKLTPKKCVNADIQ } & 291 \\
\hline Voldbjerg & \multicolumn{2}{|c|}{ HHPWGLTMACTVTECGAEWIKTDLGDLIQVTGPGGTGKLTPKKCVNADVO } & 291 \\
\hline Hjarno & \multicolumn{2}{|c|}{ HHPWGLTMACTVTFCG ADWI KTDLGDLIQVTGPGGTGKLTPNKCVINT DVQ } & 291 \\
\hline Norre A & \multicolumn{2}{|c|}{ HHPWGLTMACTVTECGADWIKTDLGDLIQVTGPGGTGKLTPNKCVINDVQ } & 291 \\
\hline Nielsby & \multicolumn{2}{|c|}{ HHPWGLTMACTVTFCETEWIKTDLGDLIQVTGPGGTGKLTPKRCVNTDVQ } & 291 \\
\hline vejer. & \multicolumn{2}{|c|}{ HHPWGLTMACTVTECETEWIKTDLGDLIQVU EPGGTGKLTPKRCVNTDVO } & 291 \\
\hline & \multicolumn{3}{|c|}{ 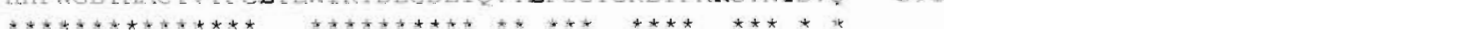 } \\
\hline F $1-13$ & \multicolumn{2}{|c|}{ MRGATDDFSYLNHLITNMAQRTECLDAHSDITASGKISSFLLSKFRPSHP } & 341 \\
\hline F1-256 & MRGATDDFSYLNHLITI & AORTECLDAHSDITASGKISSELLSKFRPSHP & 341 \\
\hline F $1-510$ & MRGATDDFSYLNHLITA & AQRTECLDAHSDITASGKISSELLSKFRPSHP & 341 \\
\hline Voldibjerg & MRGATDDESYLNHLITA & AQRTECLDAHSDITASGKISSFLLSKFRPSHP & 341 \\
\hline Hjarno & MRGATDDFSYLNHLITA & AQRTECLDAHSDITASGKISSFLLSKFRPSHP & 341 \\
\hline Norre A & MRGATDDFSYLNHLITA & AQRTECLDAHSDITASGKVSSFLLSKFRPSHP & 341 \\
\hline Nielsby & MRGATDDFSYLNHLITA & AQRTECLDAHSDITASGKISSFLLSKERPSHP & 341 \\
\hline Vejen & $\begin{array}{l}\text { MRGATDDESYLNHLITY } \\
\qquad * * * * * * * * * * * * * * * *\end{array}$ & $\begin{array}{l}\text { AQRTECLDAHSDITASGKISSFLLSKERPSHP } \\
* * * * * * * * * * * * * * * * * * * * * * * * * * * *\end{array}$ & 341 \\
\hline F1-13 & GPGKAHYLENGQIMRG & 357 & \\
\hline$F 1-256$ & GEGKAHYL LNGQIMRG & 357 & \\
\hline F1-510 & GPGKAHYLLNGQIMRG & Fig. 2. Deduced am & 10 acid sequences for the central portion of the \\
\hline Voldbjerg & GPGKAHYLLNGQIMRG & glycoprotein of 6 is & ates of viral haemorrhagic septicaemia virus. \\
\hline Hjarno & GPGKAHYLLNGQIMRG & The 216 residues ar & numbered to correspond to the amino acids of \\
\hline Norre A & GPGKAHYLLNGOIMRG & the open reading $\mathrm{fr}$ & me of the full-length glycoprotein. The symbol \\
\hline Nielsby & GPGKAHYLLNGQIMRG & (*) shows the locat & $\mathrm{n}$ of the 201 amino acids that were perfectly \\
\hline Vejen & 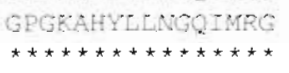 & conserved. Substit & $\begin{array}{l}\text { ions relative to the consensus sequence are } \\
\text { shown in bold }\end{array}$ \\
\hline
\end{tabular}

lyssaviruses (Bourhy et al. 1993) are in the same range (approximately $50 \%$ ) as between the glycoproteins of VHSV and IHNV (Morzunov et al. 1995) suggesting VHSV and IHNV could be considered serotypes of the same fish rhabdovirus. Both these piscine viruses differ sufficiently from their mammalian counterparts to be proposed as members of a novel genus of the Rhabdoviridae (Morzunov et al. 1995). Further molecular studies are needed to understand the evolution of the fish rhabdoviruses (Winton et al. 1992).

While the overall variation within the 216 amino acids of the central portion of the VHSV glycoprotein was approximately $7 \%$, the region of the protein from amino acid 210 to 290 contained a greater percentage $(16 \%)$ of substitutions. This unequal distribution of changes, graphically displayed in Fig. 2, may be due to the presence of localized external domains on the surface of the complex tertiary structure of the glycoprotein that would be subject to greater selection pressure. Alternatively, regions with low variation may have significant structural and/or biological constraints such that changes in these regions could be lethal.

The presence of only a single amino acid substitution within the central portion of the glycoprotein of the F1 isolate of VHSV following over 510 passages in cell 
culture was remarkable. This indicates that sequencing VHSV isolates at differing passage levels does not introduce a significant error due to random mutational drift. This finding is consistent with the 'quasispecies' concept of RNA virus populations (Domingo \& Holland 1988). Within the quasispecies, genomes with mutations at essentially any non-lethal site are being generated during every round of replication due to the high error rate of the RNA polymerase. However, the average (consensus) sequence of the population is reflective of the most fit genotype and quite stable during the absence of changing conditions or different selective pressures. If new selection pressures are imposed, the most fit genotypes within the quasispecies will rapidly predominate with a corresponding shift to a new consensus sequence. While seemingly inefficient, this strategy allows rapid adaption of RNA viruses to new hosts, to escape neutralization by antibody and to adapt to a wide range of environmental conditions. In this regard, it could be expected that the amino acid sequence of the glycoprotein of virus extracted directly from clinical material might be different than the sequence following passage of the virus in cell culture. This was shown for rabies virus by Benmansour et al. (1992). However, once a cell culture adapted strain of a rhabdovirus is selected (often within a single passage), it should remain stable unless passed at high MOI or subjected to new selective pressures. Domingo \& Holland (1988) reported that the glycoprotein of vesicular stomatitis virus (VSV) accumulated no mutations in over 400 passages in cell culture at low MOI; however, mutations rapidly accumulated during high $\mathrm{MOI}$ passage. In the case of the F1 strain of VHSV, even the series of 3 plaque clonings performed around cell culture passage 100 did not result in a single nucleotide change in the cell culture adapted strain.

As a method of precisely locating the conformationdependent, neutralizing epitopes of rhabdoviruses, wild-type virus can be grown in the presence of neutralizing monoclonal antibodies (MAbs). This applies intense selective pressure on the virus resulting in a new quasispecies that contains variants that resist neutralization. The $G$ genes of these 'escape mutants' of rabies virus, VSV, and IHNV have been sequenced and typically found to contain single nucleotide differences that led to single amino acid substitutions that correlated with resistance to neutralization, to lack of virulence, or to altered tissue tropism (Sief et al. 1985, Luo et al. 1988, Prehaud et al. 1988, Kim et al. 1994).

Many of the neutralizing epitopes of rhabdoviruses have been mapped to the central portion of the glycoprotein (Luo et al. 1988, Benmansour et al. 1991). The glycoproteins of IHNV escape mutants selected by Roberti et al. (1991) and by Huang (1993) have been sequenced and most neutralizing epitopes mapped to one of 2 antigenic sites located at amino acids 230 to 231 and at 272 to 276 (Huang 1993, Kim et al. 1994). Thus, we expected at least 1 neutralizing antigenic site would occur within the 216 amino acid region of the VHSV glycoprotein that we analyzed. The large number of mutations between amino acids 257 and 290 and the specific changes in amino acids 257 to 259 and 283 to 288 that appeared to correlate with lack of neutralization indicated that 1 or more antigenic sites may lie within this region. However, substitutions in this area may lead to conformational changes within neutralizing epitopes located elsewhere on the protein. To locate the antigenic sites with certainty, the entire glycoprotein gene of additional isolates of VHSV that resist neutralization by polyclonal or monoclonal sera will need to be sequenced and compared.

The F1 reference strain was reported to have become attenuated around cell culture passage 30 (Jensen 1965). Because we found no difference in the amino acid sequence of the central portion of the F1 glycoprotein between passage 13 and 256, we believe that the loss of virulence is related to mutations in the viral genome outside the region analyzed here. Roberti et al. (1991) used neutralizing monoclonal antibodies to select attenuated mutants of IHNV. When Kim et al. (1994) compared the glycoprotein genes of 4 of the mutants with the parental strain, they found the most highly attenuated mutant had substitutions at amino acids 78 and 218 that were thought to cause significant alterations in the secondary structure of the IHNV glycoprotein resulting in altered tissue tropism and loss of virulence.

Our results demonstrated the utility of directly sequencing RT-PCR products amplified from relatively short regions of the central portion of the glycoprotein to determine important features of the evolution, antigenicity, pathogenicity, and epizootiology of fish rhabdoviruses. While somewhat time-consuming to obtain, such data can be highly useful in determining the geographic distribution and spread of specific strains, in estimating the extent of genetic variation or rate of genetic change among isolates and in assessing the antigenic diversity among strains of the virus to assist in rational vaccine design.

Acknowledgements. The authors thank Cindy Arakawa and Bill Batts of the Northwest Biological Science Center and Niels Lorenzen and Niels Jorgen Olesen of the Danish Veterinary Laboratory for technical assistance during this project, and James Kwon, Dept of Pharmacology, University of Washington, Seattle, for his skillful operation of the ABI 373 DNA sequencer. This study was initiated by Dr Poul Vestergaard Jørgensen and conducted while he was on sabbatical leave in Seattle at the end of 1993. Sadly, his untimely death on 1 January 1995 prevented him from seeing this work in print. 


\section{LITERATURE CITED}

Benmansour A, Brahimi M, Tuffereau $C$, Coulon P, Lafay $F_{1}$ Flamand A (1992) Rapid sequence evolution of street rabies glycoprotein is related to the highly heterogeneous nature of the viral population. Virology 187:33-45

Benmansour A, Leblois $H$, Coulon $P$, Tuffereau $C$, Gaudin $Y$, Flamand A, Lafay F (1991) Antigenicity of rabies virus glycoprotein. J Virol 65:4198-4203

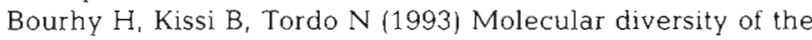
Lyssavirus genus. Virology 194:70-81

Domingo E, Holland JJ (1988) High error rates, population equilibrium, and evolution of RNA replication systems. In: Domingo E, Holland JJ, Ahlquist $P$ (eds) RNA genetics, Vol III. CRC Press, Boca Raton, p 3-36

Huang $C$ (1993) Mapping of antigenic sites of infectious hematopoietic necrosis virus glycoprotein. PhD thesis, University of Washington

Jensen MH (1965) Research on the virus of Egtved disease. Ann NY Acad Sci 126:422-426

Jørgensen PEV (1992) Recent advances in surveillance and control of viral haemorrhagic septicaemia (VHS) of trout. In: Kimura $T$ (ed) Proceedings of the OJI International Symposium on Salmonid Diseases. Hokkaido Univ, Sapporo, p 60-71

Kim $\mathrm{CH}_{1}$ Winton JR, Leong JC (1994) Neutralization-resistant variants of infectious hematopoietic necrosis virus have altered virulence and tissue tropism. J Virol 68: 8447-8453

Lorenzen N, Olesen NJ, Vestergaard Jørgensen PE, Etzerodt M, Holter TL, Thogersen HC (1993) Molecular cloning and expression in Escherichia coli of the glycoprotein gene of VHS virus, and immunization of trout with the recombinant protein. J gen Virol 74:623-630

Luo L, Li Y, Snyder RM, Wagner RR (1988) Point mutations in glycoprotein gene of vesicular stomatitis virus (New Jersey serotype) selected by resistance to neutralization by

Responsible Subject Editor: F. M. Hetrick, College Park, Maryland, USA epitope-specific monoclonal antibodies. Virology 163 : $341-348$

Morzunov SP, Winton JR, Nichol ST (1995) The complete genome structure and phylogenetic relationship of infectious hematopoietic necrosis virus. Virus Res (in press)

Nichol ST, Rowe JE, Fitch WM (1989) Glycoprotein evolution of vesicular stomatitis virus New Jersey. Virology 168 : $281-291$

Nichol ST, Rowe JE, Winton JR (1995) Molecular epizootiology and evolution of the glycoprotein and nonvirion protein genes of infectious hematopoietic necrosis virus, a fish rhabdovirus. Virus Res (in press)

Olesen NJ, Lorenzen N, Jørgensen PEV (1993) Serological differences among isolates of viral haemorrhagic septicaemia virus detected by neutralizing monoclonal and polyclonal antibodies. Dis aquat Org 16:163-170

Oshima $\mathrm{KH}$, Arakawa $\mathrm{CK}$. Higman $\mathrm{KH}$, Landolt ML, Nichol ST, Winton JR (1995) The genetic diversity and epizootiology of infectious hematopoietic necrosis virus. Virus Res 35:123-141

Prehaud C, Coulon P, Lafay F, Thiers C, Flamand A (1988) Antigenic Site II of the rabies virus glycoprotein: structure and role in viral virulence. $J$ Virol 62:1-7

Roberti KA, Winton JR, Rohovec JS (1991) Variants of infectious hematopoietic necrosis virus selected with glycoprotein-specific monoclonal antibodies. In: Proceedings of the Second International Symposium on Viruses of Lower Vertebrates. Oregon State Univ, Corvallis, p 33-42

Seif I, Coulon P, Rollin PE, Flamand A (1985) Rabies virulence: effect on pathogenicity and sequence characterization of rabies virus mutations affecting Site III of the glycoprotein. J Virol 53:926-934

Winton JR (1992) Evolution of fish rhabdoviruses. In: Kimura $\mathrm{T}$ (ed) Proceedings of the OJI International Symposium on Salmonid Diseases. Hokkaido Univ, Sapporo, p 88-95

Wolf K (1988) Fish viruses and fish viral diseases. Cornell University Press, Ithaca

Manuscript first received: March 3, 1995

Revised version accepted: June 29, 1995 